\title{
The Management of the Village Fund Allocation as an Instrument towards Economic Independence Village (Case Studies in 2 villages in Siak Regency, Province Riau)
}

\author{
Fauzi Asni, Maryunani, Sasongko, Dwi Budi \\ (Economics, Brawijaya University, Indonesia)
}

\begin{abstract}
National and regional development is inseparable part of village development activities, given the concentration of population is still dominant in the village; considering the concentration of the population still dominant located in the village, so that the village is the power base of the social economic and political need to get serious attention from the government. Construction of the village is realized in one of the forms of allocation of funds for the village. The allocation of funds village is funds given to the village of financial equalization funds of the central government and regions. This research was carried out in Siak Regenciy, Riau Province, Indonesia with two villages selected the village of Rawang White Water Bay and the villages of Siak District Merbau Dayun Subdistrict. This type of research was designed using the format verification and qualitative design approach of phenomenology (Burhan Bungin, 2007). The process of implementation of the program the allocation of funds for the village is divided into four main lines: The Process of Allocation Planning of Village funds, The process of the Allocation Management of Funds Village, The Process of Administering the Program ADD, The Process of Reporting Allocation Program of Funds Village.
\end{abstract}

\section{Introduction}

Decentralization (fiscal) is part of the scenario for the reinforcement of good governance. It is aligned with the governance changes in Indonesia which experienced a transformation in the last decade. The construction of the centralistic development has directed at model decentralize with giving some affairs/authority to the regions (decentralized) and providing room set to regions (autonomy).

When viewed from the side the importance the central government, at least there are three main objectives of decentralization. The first is called political education (education of politics). The meaning is through decentralized, expected the public will learn to recognize and understand the different issues of social, economic and political that they face; avoid or even refused to pick the candidate members of a legislature that is devoid of any qualifications political abilities expected (Smith, 1985, Maddick, 1963: 50-106, Mardiasmo $2002 \mathrm{~b}$ ). The second objective of decentralization of the interests of the central government is to provide training in political leadership (leadership training). The third objective of decentralization of central government's interest is to create political stability (for creating political stability) (Mardiasmo, 2002b).

National and regional development is inseparable part of village development activities, given the concentration of population is still dominant in the village; considering the concentration of the population still dominant located in the village, so that the village is the power base of the social economic and political need to get serious attention from the government. Construction of the village is realized in one of the forms of allocation of funds for the village. The allocation of funds village is funds given to the village of financial equalization funds of the central government and regions.

Granting allocation of funds village is a form of the fulfillment of the rights of the village for the implementation of autonomy own to grow and flourish follow growth from the village itself on diversity, participation, autonomy, empowerment, democratization of society and enhance the role of the village government in providing services and improving the welfare of the community as well as the acceleration of the development and growth of the heaved the territories. Through the allocation of funds for the village, the village has had the opportunity to manage the development, governance and social development village autonomously.

The ability and skill apparatus village is the basis of the implementation of government especially in the field of finance in managing allocation of funds village. Physical development is a manifestation of the development of the village, but at this time the village facilities and infrastructure is still inadequate in the achievement of sustainable development. Because of this, funding is a basic factor in improving the construction of the village. Problems in the village, if traced objectively shows still lack adequate economic welfare apparatus and society (Thubany, et al. 2006). This had an impact on aspects of the service to be hampered.

Unequal income it could certainly be the cause of economic reform resources village experiencing inequality. In the last year, no less than 18 village chief, Secretary Treasurer of the village and the village that has been reviewed by Kejaksanaan and police Apparatus in connection with alleged misappropriation of funds 
allocation. In General, the most urgent economic problem facing the allocation and distribution of the gap is a factor of production (Mankiw, 1999). Often the factors of production are concentrated in urban areas, which resulted in the gap of economic growth between the towns and villages. Two important factors of production are capital and labor (Mankiw, 1999). Further Mankiw argued that the amount of capital and labor will determine the amount of output which in turn will impact performance on income earned by economists from the economic activities.

In the context of the partnership between governments district/city and governments village, In fact, each has an interconnection that resonated in the development efforts, through financial transfers from government district/city to government village. From data has recorded, the support fund in the budget revenue of regional shopping Siak Regency which became the source for the allocation of funds for the village of the year 2008 amounting to Rp. 27 billion to 105 villages, in 2009 amounted to Rp. 39 billion to 105 villages and in 2010 amounted to Rp. 45 billion to 118 villages. This number is relatively large when compared to other villages of County funds allocation. Further, this area has a potential flagship in the form of petroleum mining sector. Siak Regency also has strategic potential considering its territory was in the region of the economic growth triangle "Sijori" Singapore-Johor-Riau and IMG-GT (Indonesia Malaysia Thailand Growth Triangle). With a distance of only 150 kilometers from Singapore, Siak benefited as an alternative stopover for merchant vessels in the Malacca Strait and even potentially huge relocation of industry and international trade services.

Departing from the facts above, the focus of this research will be more stressed to describe a dynamic process in the implementation of the allocation of funds for village in the Siak Regency of them e.g. behavioral change apparatus of Government, economic community, social interaction potential conflict arises, the performance of the economy, patterns of communication, decision-making mechanisms and the village government organization system, the partnership between the community and the government of the village, as well as other problems in the process of emerging spectrum. In addition, the research is expected to provide a deep analysis about the effectiveness of the administrative functions to support the sustainability of the village apparatus in decentralization.

\section{Research Methods}

This research was carried out in Siak Regenciy, Riau Province, Indonesia with two villages selected the village of Rawang White Water Bay and the villages of Siak District Merbau Dayun Subdistrict. Site selection in this study using the method of criterion based selection (Le Compte and Preissle in Alwasilah 2003: 146; Kanto, 2003: 51). This type of research was designed using the format verification and qualitative design approach of phenomenology (Burhan Bungin, 2007). Model studies on informant retrieval by using purposive model (Hagan (2006) in Berg (2007)). As well as this study uses multiple methods of data analysis, such as: focus group discussion (FGD), and case studies.

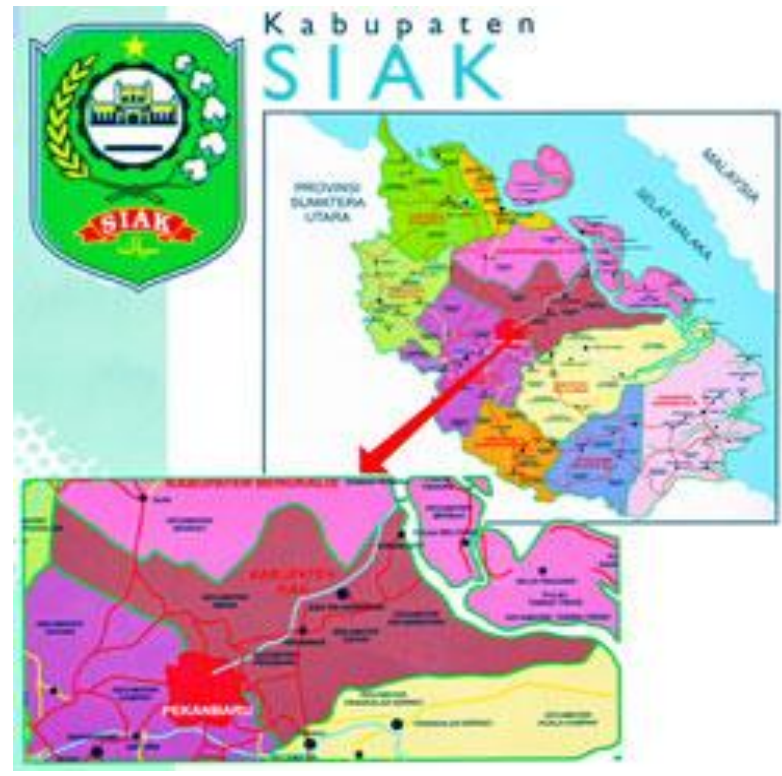

Fig.1. Research Location Map 
III.

EMPIRICAL RESULT

The process of transition from deconcentration system to the decentralize system was acknowledged as the Regional Government with autonomy. The inception of the Law Number 32 of 2004 concerning regional Governments have the authority to make policies about village in providing services, increased participation and empowerment of villagers demonstrated for the welfare of society. In the exercise of governmental functions so that the resources of Government required village runs smoothly, one of which is the need of financial resources allocation. The process of implementation of the program allocation of funds (ADD) for the village is divided into four main lines, namely planning, managing, administering and reporting. Based on the four main program process flow allocation of funds the village spelled out in detail in the picture below.

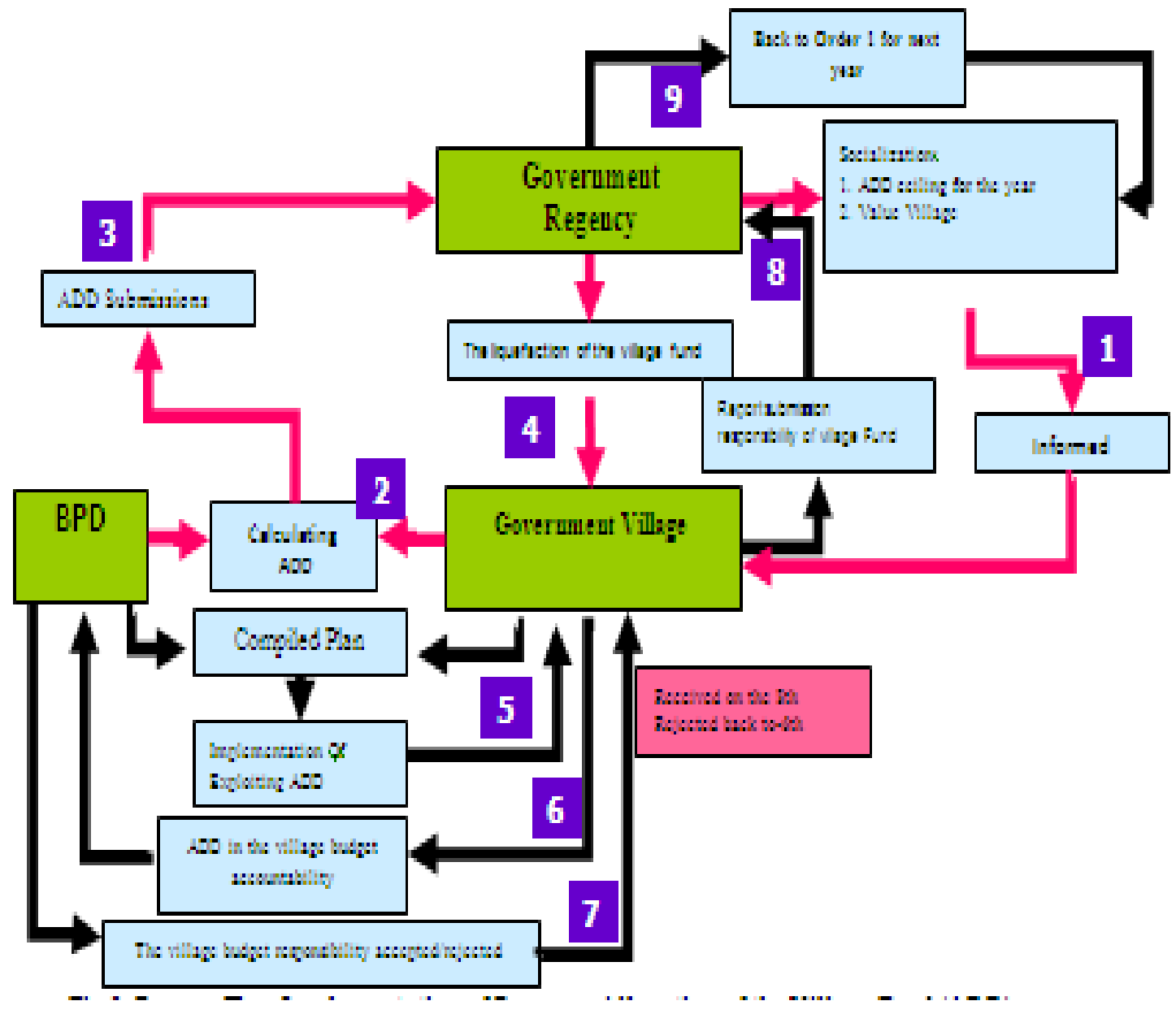

Fig.2. Process Flow Implementation of Program Allocation of the Village Fund (ADD) main lines:

The process of implementation of the program the allocation of funds for the village is divided into four

\section{The Process of Allocation Planning of Village funds}

In the process of planning the allocation of funds for the village (ADD) starts from the village fund allocation ceiling calculation year concerned and the values of the village. The village fund allocation ceiling corresponding determinations in implementation of programs with a basic allocation of funds to the village is the juridical regulation of the Minister of the Interior No. 40 year 2007 on guidelines financial management financial management guidelines of the village funds deriving from the financial centre and the equalization received by region/city to the fewest village is ten percent (10\%). Variables and weights in the channeling of funds on the allocation of funds to the village can be seen in the following table.

Table.1. Variable and Values in the Distribution of Funds Allocation Village 


\begin{tabular}{|l|c|c|}
\hline \multicolumn{1}{|c|}{ Variable } & Value & $\begin{array}{l}\text { Numeric Value (Value/the } \\
\text { number of values) }\end{array}$ \\
\hline The Number Of Residents & 4 & 0.31 \\
\hline Affordability & 3 & 0.23 \\
\hline Poverty & 3 & 0.23 \\
\hline Education & 2 & 0.15 \\
\hline PBB & 1 & $\mathbf{0 . 0 8}$ \\
\hline Groups Of Learning (ROMBEL) & $\mathbf{0}$ & - \\
\hline Early Childhood Education (PAUD) & $\mathbf{0}$ & - \\
\hline The Number of Values & 13 & 1 \\
\hline
\end{tabular}

Source: Rules of Regent Siak

At the village level planning starts with the preparation of a list of proposed activity plan (DURK) arranged by the village Council. In the various programs contained DURK is a community proposal and implementation of the guidelines would be the use of budget ADD (Sutomo, 2011). In research in the field found some facts which show that the planning process is still lacking in balance as in the deliberations of the village, people who participate in the activities of the village was still active even less impressed by the village chief in the deliberations and the delay in the process of drafting.

\section{The process of the Allocation Management of Funds Village}

Based on the regulation of the Minister of the Interior No. 37 in 2007 in article 20 paragraph 2 the use of budget funds in the allocation of funds for the village (ADD) by $30 \%$ for operational and Government apparatus shopping village, and 70\% for community empowerment. While the Regent Siak is set out in article 3 of the allocation of funds for the village (ADD) is divided into two components:

a. $30 \%$ of the size of the allocation of the funds received by the village of each village, used for the operational costs of the Government's Consultative Body of the village, the village, and The empowerment of village community.

b. $70 \%$ of the size of the allocation of the funds received by the village of each village, used to finance the activities of community empowerment.

In this research the funds managed by the research subject is the village of Rawang White Water Bay and Merbau during 2008-2012 is as follows:

Tabel 2. The Allocation of Funds in the Village of Merbau District Dayun and Village of Rawang Air Putih Siak District

\begin{tabular}{|c|c|c|c|l|}
\hline \multirow{2}{*}{ No } & \multirow{2}{*}{ Year } & \multicolumn{2}{|c|}{ The Size of the Allocation of Funds for Village (ADD) } & \multirow{2}{*}{ Description } \\
\cline { 3 - 4 } & Teluk Merbau (Dayun) & Rawang Air Putih (Siak) & \\
\hline $\mathbf{1}$ & 2008 & 150.000 .000 & 150.000 .000 & $\begin{array}{l}\text { The process is already } \\
\text { done }\end{array}$ \\
\hline $\mathbf{2}$ & 2009 & 358.740 .075 & 372.572 .714 & $\begin{array}{l}\text { The process is already } \\
\text { done }\end{array}$ \\
\hline $\mathbf{3}$ & 2010 & 274.851 .732 & 361.042 .228 & $\begin{array}{l}\text { The process is already } \\
\text { done }\end{array}$ \\
\hline $\mathbf{4}$ & 2011 & 265.945 .800 & 361.237 .700 & $\begin{array}{l}\text { The process is already } \\
\text { done }\end{array}$ \\
\hline $\mathbf{5}$ & 2012 & 690.722 .050 & 453.372 .800 & Process \\
\hline \multicolumn{2}{|c|}{ Total } & $\mathbf{1 . 7 4 0 . 2 5 9 . 6 5 7}$ & $\mathbf{1 . 6 9 8 . 2 2 5 . 4 4 2}$ & \\
\hline
\end{tabular}

Source: The Local Government Finance Siak

Based on the table to see that each year the acceptance of allocation of funds for the village continues to experience growth seen yet of both these villages the growth seen in the village of Teluk Merbau compared to the village of Rawang white water. In 2008 the initial distribution of funds allocation fund village in the Siak Regency of both these villages get a proportion of the allocation of funds of the same magnitude but the village since there are models of allocation of funds proportionate distribution of second village the village into a variable. 
In field observations in mind that still less can the functions of apparatus in the village in running financial management of ADD in activities which have been compiled in a list of proposed activity plan (DURK). The lack of synergy between the villages of apparatus in research is seen mainly from the function of the BPD is less feared would lead to programs running are not the maximum because of the weakness of the control.

\section{The Process of Administering the Program ADD}

The process of administering the allocation of funds is the authority of village treasurer village of good acceptability and administering expenses. Administering the reports is recorded in a document in the form of cash book, cash book helpers. The situation regarding the implementation of the process of administering program funding allocation in Siak Regency in each village are still often encountered a number of constraints such as:

1. Some regulations are often considered complicated as regulatory imposition of taxes, regulations, procurement tenders for development activities whose value is above a hundred million, as well as several other regulatory constraints.

2. The level of ability in implementing village administering apparatus which still trouble although the administering forms have been prepared.

3. The rules often change every year so it's always happened in the adjustment fund allocation village, teachers, early childhood education, madrasah and study groups the payout is not the responsibility of the village, but now the payment of teachers, early childhood education, madrasah and study groups become the responsibility of the village.

4. Supporting infrastructure the village a less adequate as some villages are still constrained by the power supply and still often hit by power outages so that the proper functioning of the equipment in the office of the village.

To reduce the obstacles that arise in the process of administering the local government has been seeking some way i.e. do invite the village apparatus for coaching and training routine that is performed annually, providing bachelor's companion in every district.

\section{The Process of Reporting Allocation Program of Funds Village}

The process of reporting responsibility is the last process after the process of administering and process of implementation of the allocation program of funds for the village in a year. Next was the responsibility of the secretary to draw up a draft regulation village the village about the accountability implementation of budget revenue and expenditure of the village and the draft decision of the head of the village. After getting the approval of the head of the village and the village's consultative bodies (BPD) then the next draft is set to rule later in the village pass to the local government District of Siak at the latest one month after the fiscal year ends.

Based on the results of the study it can be concluded that there is accountability for funds allocation activity of the village, although there were delays in the preparation of allocation of the funds village. Pay attention to the conclusions on the process of implementation of the above policy, then it can be drawn the conclusion that the process of implementation of the policy on the allocation of funds is a village in the Siak District has gone well.

In more depth, the participation of the public in the era of decentralization is the absolute element for the implementation of the development. People are no longer placed in position as an object of development, but as active subjects who are planning, implementing, overseeing development and enjoy the results. Consequently, there are still needed the political will from decision makers (government) that based on vision changes so rapidly. Such a change is when is meant positively, to be offset by changes in local governance is good (good local governance) in the context of the village a more democratic, transparent and accountable. The implications are apparent from the results of this study indicate that the low level of participation cannot be denied it factually happened.

Implementation of the allocation process is indeed a village based on the State of the community and the village. For a list of proposed work plan which is composed is a reflection of the development needs of the communities and villages, for example of the potential of the village. Budget allocation appears to encourage village empowerment in agriculture, infrastructure, strengthening the economy and others, in addition, such a State of society which is still relatively high poverty rates. So expect the realization, the allocation of funds to the village can afford to encourage development in sectors that are considered potential and productive activities could push citizens.

In General in the process of implementation of the appropriations funds village look that each village has run a public participation process. The village fund allocation arrangement has involved parties in the village. Neither the village government itself as well as managing the allocation of village funds BPD, LPMD and other parties interested in the process of rural development. Implementation of the allocation of funds in the research done by location is quite transparent and no the most dominate. Although conflicts of interest still exists but in 
general can be addressed through intensive communication, such as occurred in the village of Rawang Air Putih and Teluk Merbau.

Based on the results of the research findings in the field of development dimension implies that the social, economic, political and social relations as a whole in a routine that is executed by the Government of the village and in general support the participation of the public (the public) has already started to rise. Although the macro glasses, this condition has not been offered a relation between community cohesiveness and strong village government as the complexity of problems, among others:

a) Inconsistencies between planning and financing programs;

b) Low levels of transparency and accountability in the utilization of public financial resources;

c) The low level of involvement of interested actors and public participation in policy formulation;

d) The lack of performance assessment policy, planning and implementation, in a comprehensive and sustainable.

e) There is inconsistency between the policies adopted by the various public organizations and between the macro and micro policy and between policy and implementation, as well as

f) Ineffective performance assessment policy, planning, and execution of the activity itself.

In the process of implementation of the program at the village fund allocation success rate achieved is certainly a result of several factors. Factors observed in this study are

\section{a) Communication}

Communication is the process of the interaction of delivering messages via a mediator. The influence of the communication factor on the implementation is on clarity and content of the message to be understood thoroughly by the receiver of the message or program. In this communication factor will be viewed from a variety of observed phenomena associated with the author in the field of policy implementation process allocation village.

Based on the results of interviews conducted by investigators with the informant above it can be seen that the intensity of socialization village allocation policy is still lacking because socialization is only carried out by a team of district to district, village heads, village consultative body, and the team leader mover advisor village family welfare, whereas socialization from village to village heads and other members of the community there. This results in the participatory development approach, where it is assumed that the development will be successful if the community is involved in the development process, ranging from policy formulation, formulation, implementation and evaluation of expediency. In such development, the control of the factors of production will be higher the ability of communities to plan, implement and supervise (Baswir, 2003). The information known only to a few parties, may hamper the implementation of participatory development in the implementation of the allocation of village funds.

\section{b) Clarity of communication}

Based on the results of interviews conducted with the researcher's informant can be known that there is a clear message from the village fund allocation policy implementers. Institutionally related processes (Yustika, 2006), institutional refers to efforts to design the pattern of interactions between economic actors so that they could conduct transactions, it is apparent from the statements of some of the officials involved in the implementation of the allocation of funds for the village, concerning the clarity of the design patterns that become the reference implementation of the allocation of funds for the village.

\section{c) The consistency of the message}

Based on the results of interviews conducted with the researcher's informant can be inferred that there has been a consistency of message, meaning that there are no conflicting messages. From the results of research of the phenomenon of communication above, then it can be summed up as follows:

The intensity of the village fund allocation policy socializing less because socializing is only implemented by the district level, addressed to the head, head of the team of movers Builder community welfare districts, the village head, village, consultative body, and the head of LPMD propulsion Team Builder family welfare village, while socialization from the head of the village to the village and other community residents. As for the clarity of information, research results revealed that the provisions of the technical instructions the village fund allocation has definitely accepted by the executor. Likewise there is a consistency of message; it means there is no conflicting policy message from one command to another command policy.

In the management of funds from the ADD a principle that should be adhered to the principles of the management of the grant, should follow the following principles: 
In the fund management of ADD are principles that must be adhered to the principles of the management of these funds, must follow the following principles:

1. Transparency, the entire program / activities to be implemented should be known by the whole society with easy and open. Village Budget transparency is a key requirement for realizing the village government is good, clean and responsible.

2. Participation, which all members of society should play an active role in the planning, implementation, and monitoring of activities by holding fast to the village assembly as the highest decision making forum.

3. Accountability, the entire program/activity must be accountable both technically and administratively. The village government is responsible for the receipt and expenditure in accordance with the program approved by the Siak Regent.

4. Sustainability, the results of the activities can be utilized and developed by the whole society. Financial aid funds to the village government should be used for activities that can stimulate community participation and self-help.

To achieve that goal then the regents also set rules regarding the guidance and supervision of local government referred to in paragraph (2) of article 13 A above, include:

a. Provide guidance and implementation guidance allocation of village funds;

b. Provide guidance and training to the village head, village and village treasurer in respect of the allocation of village funds;

c. Develop and oversee the implementation of the allocation of village funds, and

d. Provide guidance and guidance of financial administration for the village.

From the results of research to the achievement of policy objectives, namely increasing governance, and social development, increasing the ability of an association of villages in the planning, implementation and control of development and to encourage increased participation of non-governmental mutual aid societies, can bedescribedasfollows:

i. Increased governance, and social development.

Based on the results of interviews conducted by investigators with the informant above it can be seen that one of the village fund allocation, namely the increasing governance, and social development has been basically achieved.

ii. Ability of an association of villages in the planning, implementation and control of development.

Based on the results of interviews conducted by investigators with the informant above it can be seen that the Institute of Rural Institutions not increase capacity optimally due not so much involved in planning the use of village funds allocation, there is even a village without going through the planning process as the existing guidelines, not been involved in the implementation of the allocation of village funds and also have never been involved in the evaluation of the implementation of the allocation of village funds.

iii. Improve the distribution of income, employment and business opportunities for rural communities in developing socio-economic community.

From the results of information obtained in the field that the village of Teluk Merbau, Dayun District more advanced when compared with village of Rawang Air Putih, Siak District. It can be seen that the implications of granting allocation fund village in the village of Teluk Merbau could be more optimized than village of Rawang Air Putih.

Another thing that causes more advanced Merbau Bay village is the presence of several factors, among others:

a. Palm plantations are managed successfully.

b. There is an agreement that approximately $2 \%$ of oil revenues from the local community is given for a typical village (the result of this fundraiser people can buy land (other land) to the local community land, the construction of the mosque, road repair, etc.).

c. Management of the funds allocated in the village which are input into the savings and credit cooperatives (worn by the people and for the people).

Both civic institutions upgrade in the village in the planning, implementation and control of development. The achievement of this goal is not running optimally, since the only viable institutions involved in the preparation of a plan of activities while in implementation and control are not involved.

iv. Non participation Mutual Aid Society.

Lack of public participation in the activities of the allocation of village funds, which is only $30.53 \%$ as compared with funds received in the region recognized by the Head Siak District.

Based on the results of interviews conducted with the researcher's informant can be noted that the participation of non-governmental mutual society in the implementation of the allocation of the village Fund to decrease. In general social capital is very influential in the implementation of the allocation of funds for the 
village, as in the pass by the village chief Rawang Air Putih, where social capital can be approached from two perspectives: first, social capital is approached from the perspective of the offender (actor perspektive). This approach was formulated by Bourdieu's view of social capital include the resources where the individual offender can use it because of his ownership of the network exclusively (exclusive network). Second, look at the social capital of the community perspective. At Rawang Air Putih village social capital performed by actors approach in this case the people who use its ownership of the final outcome of the implementation of the allocation of village funds, in this case the bridge infrastructure.

With the results of three studies on the phenomenon of the achievement of policy objectives allocation of funds above the village, namely an increase in implementation of governance, reconstruction and development, the village institutions did not have an increased ability to optimally in the planning, implementation and control of the construction as well as the participation of non-governmental mutual society in the implementation of the allocation of funds to the village declined, then it can be concluded that the achievement of the policy objectives of the allocation of funds is not running optimally village.

Based on the results of interviews with respondents of the policy implementation, the phenomenon of the process of implementation of the policy on the allocation of funds and the achievement of policy objectives allocation of funds for the village it can be concluded that the funds allocation policy has been implemented in accordance with the existing provisions, but its implementation has not been able to achieve policy objectives optimally.

Based on the results of the interviews with the informant, it can be noted that the implementation of the allocation of this village have been met, i.e. all the villages to carry out allocation policies village quite well. However, if the statement attributed to Van Metter and Van Horn (in Winarno, 2002: 102) that limit the implementation of the public as the actions carried out by individuals (or groups) that directed the government and private sector to achieve the goals that have been specified in the previous policy decisions.

It can be seen from the achievement of the purposes of the allocation of funds for the village. The first improvement of governance, and social development, the achievement of this goal has been accomplished optimally. Achievement of this objective to be optimal due to the villages in the District of Siak and District of Dayun categorized village is poor so badly need funds in order to increase implementation of governance, reconstruction and development, based on the data that researchers found in the Siak District and Sub Dayun. While the allocation of funds for village in the Siak District village of Rawang white water contributed Rp. 1.698.225.442,-(last 5 years), the allocation of funds to support an increase in the very village governance, reconstruction and development.

While in Dayun village of Teluk Merbau Allocation village in the Siak District village of Rawang white water contributed Rp. 1.740.259.657,-(last 5 years), the allocation of village funds so support the promotion of governance, development and social aspects of income and also assisted the local community where the village specifically for Teluk Merbau District Dayun that their communities are mostly migrants from the Javanese people, mostly people of this village have palm land which is managed by good, so that should help in terms of revenue when compared to Rawang Air Putih village where the population is predominantly native (host) the Siak itself.

From the results of the study in relation to the implementation of resource allocation village, there are several factors driving and inhibiting. Some of the driving factors are:

a. The ability of the Executive to give encouragement to people to participate in the activities of the village fund allocation, although only in the form of manpower and material.

b. The ability of implementing the policy allocation village in identifying and resolving problems in the implementation of the allocation of funds for the village.

c. Completeness means village in supporting infrastructure policies for the allocation of funds for the village.

d. There is community support to the Fund allocation policy of the village in the form of manpower and material.

While restricting factor in resources is now the low education of the village fund allocation, implementers so understanding about implementing the village fund allocation is less, as well as the lack of adequate income support to the village, giving rise to a lack of financial support in the implementation of the policy.

\section{CONCLUSIONS AND RECOMMENDATIONS}

Based on observations and analysis conducted in the previous chapter, this research resulted in the following conclusions:

1. The dynamics of program implementation in the funds allocation village of Teluk Merbau and the village of Rawang Air Putih in terms of planning, managing, administering, and reporting of the implementation of the mechanism were in accordance with a predetermined standard although there are still some shortcomings in implementation. 
2. Community participation, institutional and social capital in the implementation of program allocation of funds in the village of Rawang Air Putih and the village of Teluk Merbau played an important role in efforts to make implementation more efficient and effective. Such as reducing the occurrence of asymmetric information, planning is lacking according to the needs of the village, the occurrence of irregularities as well as other problems that would make the implementation of ADD becomes less efficient and effective.

3. The allocation of program funds this village can make instruments for the village to be independent it looks with some of the things that is:

a. Improve the organization of the government of the village government services in carrying out development and society, in accordance with those powers.

b. Enhancing civic institutions in the village in the planning, implementation and control of development and participatory in accordance with potential.

c. Increase the equity income, employment opportunities and a chance to try for the villagers in the framework of socio-economic development of the community.

d. Encourage the participation of non-governmental mutual society.

Based on the results of this research it can be recommended:

1. Because there are still some weaknesses with respect to the ability of the village apparatus technical training program should still have to be constantly improved.

2. Encourage increased community participation because with the increasing participation of the community is expected to be more focused implementation of ADD and precise. Increased community participation is also expected to reduce the presence of asymmetric information that could lead to the implementation of the ADD becomes ineffective and inefficient.

3. Institutional Strengthening of the enforcement of the existing rules so that the implementation can be in accordance with the applicable procedures.

\section{REFERENCES}

[1]. Anonymous. UU No. 32 tahun 2004 tentang Pemerintahan Daerah, Departemen Dalam Negeri Republik Indonesia, Jakarta.

[2]. Anonymous. UU No. 33 tahun 2004 tentang Perimbangan Keuangan antara Pusat dan Daerah, Departemen Dalam Negeri Republik Indonesia, Jakarta.

[3]. Anonymous. PP No. 72 tahun 2005 tentang Desa, Departemen Dalam Negeri Republik Indonesia, Jakarta.

[4]. Anonymous. 2006. Urgensi dan Relevansi ADD Dalam Konteks Pengembagan Kapasitas Desa di Tuban Dalam Mengelola Pemerintahan dan Pembangunan. FPPD: Jakarta. Dipublikasikan.

[5]. Mankiw, N. Gregory, (1999). Teori Makro Ekonomi, Edisi Keempat. Erlangga: Jakarta.

[6]. Mardiasmo. 2002b.Otonomi dan Manajemen Keuangan Daerah: Serial Otonomi Daerah. Penerbit ANDI Yogjakarta: Yogjakarta.

[7]. Phillips, Kerk. L., dan Garry Woller. 1997.Does Fiscal Decentralization Lead to Economic Growth?, Working Paper, Number 97-7, September, 1-13

[8]. Sutopo, Hery. 2005. Kesiapan Aparatur Pemerintah DesaDalam PelaksanaanOtonomi DaerahDi Desa Karangsambung Kecamatan Kalibawang, Kabupaten Wonosobo. Unness: Semarang. Dipublikasikan.

[9]. Thubany, Syamsul Hadi, Muhimuddin, Ismail Amir. 2006. Desentralisasi Keuangan; Pandang Kebijakan Pemda Kepada Masyarakat Desa. Bina Swagiri-FITRA Tuban. Nuansa Aksara: Yogyakarta.

[10]. Tjokroamidjojo, Bintoro, 2000, Good Governance (Paradigma Baru ManajemenPembangunan), UI Press, Jakarta. 